Article

\title{
River-Wide Habitat Availability for Fish Habitat Guilds: Implications for In-Stream Flow Protection
}

\author{
Jonathan Spurgeon ${ }^{1, *}$, Mark Pegg ${ }^{2}$, Piotr Parasiewicz ${ }^{3}$ and Joe Rogers 4 \\ 1 Department of Aquaculture and Fisheries, University of Arkansas at Pine Bluff, 1200 N. University Dr., \\ Pine Bluff, AR 71601, USA \\ 2 School of Natural Resources, University of Nebraska-Lincoln, 3310 Holdrege St, Lincoln, NE 68583, USA; \\ mpegg2@unl.edu \\ 3 Department of River Fisheries, S. Sakowicz Inland Fisheries Institute, 10-719 Olsztyn, Poland; \\ riverpiotr@gmail.com \\ 4 Rushing Rivers Institute, 592 Main St, Amherst, MA 01002, USA; joerogers@rushingrivers.org \\ * Correspondence: spurgeonj@uapb.edu; Tel.: +1-870-575-8105
}

Received: 9 May 2019; Accepted: 28 May 2019; Published: 30 May 2019

check for updates

\begin{abstract}
The variation in river discharge alters habitat heterogeneity with implications for the distribution of fish species with different habitat requirements. Assessments of habitat availability following changes in river discharge are difficult to apply at broad spatial scales and with relevance to multiple species. We used a MesoHABSIM modeling approach to quantify river-wide changes in habitat availability for five fish habitat guilds under three river discharge levels along the Niobrara River, NE, USA. We used a time-series of river discharge (1958-2010) to create uniform continuous under-threshold habitat duration curves that identified habitat conditions that may result in periods of stress for fish communities along the Niobrara River. Habitat availability for each fish habitat guild was dependent on river discharge and location along the river. Habitat availability for fish habitat guilds ranged from 5\% to $49 \%$ of the total channel area suggesting habitat availability may, at times, be limited. We provide river discharge guidelines for bioperiods that limit the frequency and duration of stressful habitat conditions. Understanding interactions between river discharge and habitat availability through time and at river-wide scales may aid in managing for ecological integrity by including protection of river discharge variability to support multiple fish habitat guilds.
\end{abstract}

Keywords: habitat; flow regime; river; fish; guild; MesoHABSIM

\section{Introduction}

The heterogeneity of habitat in a river is supported in part by variability in river discharge [1,2]. Rivers are naturally dynamic with discharge patterns influenced by seasonal precipitation, temperature, and ground-water connections [3]. Additionally, rivers can exhibit multiple discharge patterns along their lengths [4]. The variability in river discharge can influence the spatial and temporal availability of aquatic habitat $[5,6]$. For instance, increases in river discharge can enable connectivity to side-channels or floodplains whereby increasing the amount of habitat available for fishes to carry out multiple life-requisites [1]. Periods of decreased river discharge, however, can reduce the distribution of habitat types (e.g., riffle complexes and side-channels) through dewatering and may necessitate movement by fishes to refuge areas or result in declines in abundance and distribution [7]. Variability in river discharge, thus, facilitates heterogeneous habitat conditions that can influence fish species presence and abundance and subsequently fish community structure and dynamics [8,9]. River discharge and habitat availability relationships have traditionally been evaluated at spatial scales that limit river-wide inference [6]. Evaluating habitat availability (i.e., percent of channel area) at a river-wide scale and 
under different river discharges may provide the measureable unit required for the maintenance or establishment of in-stream discharges within the natural variability of the river system.

Establishing relationships between river discharge and fish habitat availability at a river-wide scale necessitates habitat data that is representative of the fish community [10]. Fish species are not evenly distributed along the length of a river [11] and, thus, individual species' habitat data may not be available for a given river reach. The use of fish habitat guilds-where groups of fish species possess similar habitat needs-may enable assessment of river-wide habitat availability as the relative proportion of fish habitat guilds present can indicate changes in habitat availability [11]. Additionally, guild structure can be transferrable to different areas including river systems and potentially river reaches with dissimilar species [10]. The use of fish habitat guilds may also afford greater inclusion of discharge variability inherent to the river system. For instance, fish habitat guilds represent the integration of several species-habitat responses and provide a more ecosystem-based perspective compared to single-species habitat assessments $[12,13]$.

This study assessed habitat availability at different river discharges for fish habitat guilds along the Niobrara River, a large braided river system in the Great Plains, USA. Relationships between river discharge and habitat availability at river-wide scales has yet to be done in braided river systems despite the vulnerability of these systems to systemic human alteration including fragmentation and water withdrawals. Braided river systems in arid to semi-arid climates are particularly vulnerable as increased human demand for water resources and changing precipitation patterns associated with climate change exacerbate pressure on limited water supplies [14]. The objectives of this study were to: (1) Quantify habitat availability at three river discharge levels for fish habitat guilds across the length of the Niobrara River, (2) determine the suitability of aquatic habitats for each fish habitat guild, and (3) develop spatially and temporally explicit river discharge guides based on long-term river discharge data. We used the MesoHABSIM modeling framework to assess habitat availability [15]. The MesoHABSIM approach allows regional-scale assessments by modifying the data acquisition technique and analytical approach of similar models (e.g., PHABSIM) through the collection of species and habitat information at the meso-habitat scale rather than at the micro-habitat scale $[15,16]$. There are three components to the MesoHABSIM modeling framework: (1) A hydromorphologic model that describes the spatial mosaic of habitat availability, (2) a biological model that describes habitat use by fish habitat guilds, and (3) a habitat model that quantifies useable habitat at different river discharges [15]. Mesohabitats are defined on the spatial framework of hydromorphologic units (HMUs; e.g., pools, riffle, and slackwater) as a function of occurring hydraulic (i.e., depth and velocity) and morphometric (i.e., topography, and cover) patterns. The distribution of HMUs with accompanying habitat characteristics is then mapped under multiple discharge conditions. Following MesoHABSIM modeling, we also implemented a time-series analysis to determine when river discharge may limit habitat availability. We provide river discharge guides based on bioperiods where bioperiods are designated calendar periods corresponding to general life stages of the fish community within the system and during which time the management of discharge and habitat conditions is of particular importance to a targeted fish habitat guild [15]. Collectively, this work may aid the development of a river discharge policy that reflects natural variability at river-wide spatial scales and may facilitate maintenance of fish communities including the current fish community of the Niobrara River.

\section{Materials and Methods}

\subsection{Niobrara River}

The Niobrara River basin covers approximately $32,600 \mathrm{~km}^{2}$ with a large portion (90\%) of the Niobrara River traversing through northern Nebraska, USA (Figure 1). The Niobrara River is an alluvial river with distinct hydrogeomorphic characteristics-alternating wide and narrow stream valleys (i.e., $<300 \mathrm{~m}$ to $>900 \mathrm{~m}$ ) and channel widths (i.e., $<10 \mathrm{~m}$ to $>300 \mathrm{~m}$ )—along the longitudinal gradient of the river [17]. The Niobrara River is a groundwater dominated system receiving inflow from the Ogallala 
and High Plains aquifers $[17,18]$. Additionally, seasonal precipitation patterns induce variation in river discharge. Mean monthly discharges—based on mean monthly discharge data from 1938 to 2016-range from $34 \mathrm{~m}^{3} \mathrm{~s}^{-1}$ (SE = 1.27; August) to $72 \mathrm{~m}^{3} \mathrm{~s}^{-1}$ (SE = 2.35; March) in the eastern portion of the basin near the confluence with the Missouri River (Figure 2; USGS Gauge 06465500). Water development within the basin (e.g., diversions and impoundments) has caused reductions in discharge and channel constraining [17]. However, the contribution of groundwater and seasonal precipitation patterns maintain base discharges and seasonal variability within the Niobrara River $[17,19]$ unlike many other Great Plains systems.

We chose one study site within each of sixteen river sections (i.e., total of 16 sites) following recommendations from previously quantified habitat breaks [17] as well as foot and aerial reconnaissance surveys along the length of the Niobrara River. We selected each study site using previously collected cross-sectional measurements from [17]. The proportion of HMUs at each site was similar to the larger-scale section based on a cross-section analysis of each of the 16 sections. To evaluate the section representativeness of each study site, we used boxplots of the associated morphometric data. Morphometric data included channel slope, sinuosity, width, ratio of channel wetted width to total channel width, coefficient of variation of channel width, ratio of channel width to valley width, the number of channels, mean stream power, and the 90th percentile stream power [17]. We compared box plots of the section and site to ensure that the median, lower quartile, and upper quartile were similar. If not similar, the study site was expanded until section and site boxplots were similar. If a study site expanded beyond 6 river kilometers $(\mathrm{rkm})$, a new site was selected and the process of measuring site representativeness was repeated. The sixteen sections (Figure 1) lie within three river segments that differ by fish community diversity as well as channel morphology, channel width, and valley width [17]. Segment 1 (sections 1-3; $193 \mathrm{rkm}$, mean channel width $=313 \mathrm{~m}$, mean valley width $=939 \mathrm{~m}$ ) includes the lower Niobrara River and delta region upstream to Spencer Dam. Segment 2 (Sections 4 and 5; $309 \mathrm{rkm}$, mean channel width $=37 \mathrm{~m}$, mean valley width $=277 \mathrm{~m}$ ) includes the braided sites between Spencer Dam and Norden Chute. Segment 3 (sections 6-16; $230 \mathrm{rkm}$, mean channel width $=6 \mathrm{~m}$, mean valley width $=991 \mathrm{~m}$ ) includes the remainder of the Niobrara River west of Norden Chute to Box Butte Reservoir dam.
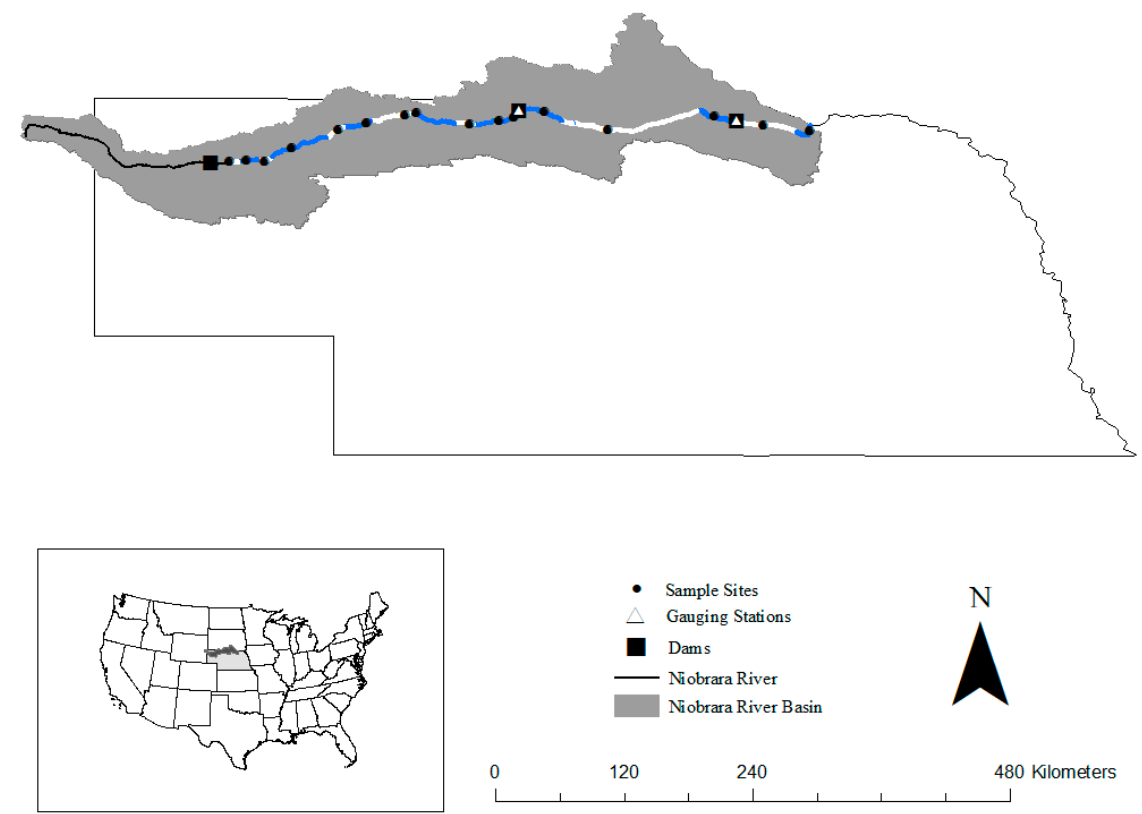

Figure 1. Fish sample sites (filled circles) and locations of river sections (alternating blue and white areas along river) representing unique hydrogeomorphic conditions and gauging stations (filled triangles) in the Niobrara River located in Nebraska, USA. Inset shows the Niobrara River basin outlined in gray. River discharge is from west to east. 


\subsection{Guild Specific Habitat Availability}

\subsubsection{Fish Species Surveys}

We collected fish data in HMUs using a prepositioned area electrofishing (PAE) grid. Fish surveys occurred at each of the 16 sites in summer 2010. A Smith-Root 2.5 GPP electrofishing unit powered using a $2500 \mathrm{~W}$ generator applied pulsed-DC at 1-3 amps and 60 pulses s$^{-1}$ to the PAE grid. The PAE grid included $32 \mathrm{~mm}$ plastic pipe and $3 \mathrm{~mm}$ stainless steel cable formed into $2 \mathrm{~m} \times 6 \mathrm{~m}$ rectangles. The PAE grid sat undisturbed for at least 10 minutes to allow fish to redistribute within the grid following deployment [20]. We used a stationary bag seine ( $4 \mathrm{~m} \times 4 \mathrm{~m} \times 4 \mathrm{~m} ; 6.35 \mathrm{~mm}$ netting), positioned at the downstream end of the PAE grid to capture stunned fish. Active sampling with dip nets was performed to capture any lodged individuals. We collected data from a minimum of 15 PAE grids per site (i.e., used the PAE grid in at least 15 HMUs per site) to collect fish community data. The proportion of HMUs sampled was based on the proportion of HMUs identified during mapping surveys at each site (see below). The placement of each PAE intended to capture microhabitat complexity within each HMU and included placing the PAE around any physical structure present within the HMU (e.g., boulders or coarse wood). We identified captured fish to species, measured (i.e., $\mathrm{mm}$ total length) each fish, and released individuals back into the river. Fish that could not be identified in the field were preserved ( $10 \%$ buffered formalin) and identified in the laboratory.

\subsubsection{Habitat Mapping Surveys}

We estimated the spatial distribution of HMUs at study sites using habitat mapping surveys at three river discharge levels. The three discharge levels approximated a sustained spring high discharge, a summer low discharge, and an intermediate discharge and were chosen to depict river discharges that encompassed as much annual variability as possible. Segment 1 discharges included $0.45 \mathrm{ft}^{3} \mathrm{~s}^{-1}$ $\mathrm{mi}^{-1}$ (cfsm; $4228 \mathrm{cfs}$, spring high discharge), $0.1 \mathrm{cfsm}$ (1208 cfs, summer low discharge), and $0.25 \mathrm{cfsm}$ ( $2416 \mathrm{cfs}$, intermediate discharge). Segment 2 discharges included $0.37 \mathrm{cfsm}$ (3234 cfs, spring high discharge), $0.1 \mathrm{cfsm}$ (1078 cfs, summer low discharge), and $0.22 \mathrm{cfsm}$ (2156 cfs, intermediate discharge). Segment 3 discharges included $0.16 \mathrm{cfsm}$ ( $1076 \mathrm{cfs}$, spring high discharge), $0.1 \mathrm{cfsm}$ ( $359 \mathrm{cfs}$, summer low discharge), and $0.04 \mathrm{cfsm}$ (359 cfs, intermediate discharge). We constructed habitat maps for study sites by estimating the location and size of each HMU using GPS and ArcPad (ESRI) software in conjunction with high-resolution aerial images obtained with a drone a few days prior to the survey. Specifically, drone flights were conducted using an AggieAir Flying Wing (fixed-wing unmanned aerial vehicle) within $24-48 \mathrm{~h}$ of sampling to ensure similar conditions when ground truthing. Data from the flights were converted to a georeferenced map and each HMU was visually identified. We outlined each HMU creating geo-referenced polygons. In the wide, braided locations of the Niobrara River (sections 1-5), we pre-annotated (i.e., using areal imagery alone) the HMUs at the study site based on appearance. We investigated each HMU to validate the annotation, collected information on cover and hydraulic conditions, and made any necessary changes to the HMU boundaries. Within each HMU, we measured water velocity, depth, and substrate in at least 10 random locations. The dominant substrate was estimated using the choriotop classification system according to [21]. We measured depth and water velocity using a wading rod and Marsh-McBirney Flo-Mate 2000. Physical habitat characteristics including boulders, concrete block, over-hanging and in-stream vegetation, wood structure, undercut banks, and shallow margin were annotated for each HMU polygon using three categories: Absent $<5 \%$, present, and abundant $>50 \%$ of HMU area. We estimated embeddedness as loose (e.g., dislodges easily), embedded (e.g., bottom material firmly in place), or solid (e.g., bedrock).

\subsubsection{Development of Fish Habitat Guilds}

We used species data collected in each HMU (using the PAE grid) to define fish guilds within the Niobrara River. Hierarchical cluster analysis identified fish guilds based on fish species occurrence associated with habitat characteristics. Fish guilds were described using species level data and did 
not account for different habitat uses during ontogenetic development (i.e., larval fish were not included in development). We used a total of six habitat characteristics for guild development and standardized data prior to cluster analysis. We measured mean column velocity $\left(\mathrm{cm} \mathrm{s}^{-1}\right)$ and depth $(\mathrm{cm})$ for each PAE grid within a HMU. We measured water velocity and depth using a wading rod and Marsh-McBirney Flo-Mate 2000. The dominant substrate was estimated for each PAE grid within a HMU using the choriotop classification system [21]. We collected dissolved oxygen (mg $\left.\mathrm{L}^{-1}\right)$, temperature $(\mathrm{C})$, and conductivity $\left(\mathrm{S} \mathrm{cm}^{-1}\right)$ for each PAE using a YSI 556 MPS multimeter. We calculated mean values, by species, for continuous habitat characteristics and used percentages of substrate type observed. Continuous variables were $\log (x+1)$ transformed, while proportional variables were arcsine square root transformed. Ward's agglomerative hierarchical method was used to group species into different clusters. We used cubic clustering criteria to identify the appropriate number of clusters [22]. The hierarchical cluster analysis suggested the presence of five unique fish habitat guilds in the Niobrara River including: (1) Lobate margin, (2) run, (3) riffle, (4) slackwater, and (5) habitat generalist (Table 1). Full detail of the guild formation approach is available in Pegg et al. [23].

Table 1. Description of fish guilds determined for the Niobrara River using empirical fish species data collected within hydromorphologic units using prepositioned area electrofishing. Detail of guild formation is available in Pegg et al. [23].

\begin{tabular}{|c|c|c|}
\hline Guild Name & Guild Members & Guild Description \\
\hline Lobate Margin & $\begin{array}{l}\text { Bigmouth shiner, Notropis dorsalis } \\
\text { Red shiner, Cyprinella lutrensis } \\
\text { Plains topminnow, Fundulus sciadicus } \\
\text { Fathead minnow, Pimphales promelas } \\
\text { Brook Stickleback, Culaea inconstans, Age } 0 \\
\text { Channel catfish, Ictalurus punctatus }\end{array}$ & $\begin{array}{l}\text { Inhabit areas of low velocity and shallow } \\
\text { depths on the margin of channels. May } \\
\text { include areas with lower dissolved oxygen } \\
\text { and fluctuating temperatures. }\end{array}$ \\
\hline Run & $\begin{array}{l}\text { Sand shiner, Notropis stramineus } \\
\text { Emerald shiner, Notropis atherinoides, }\end{array}$ & $\begin{array}{l}\text { May include main channel areas with } \\
\text { greater velocities and depths. }\end{array}$ \\
\hline Riffle & $\begin{array}{c}\text { Brassy minnow, Hybognathus hankinsoni, } \\
\text { Central stoneroller, Campostoma anomalum } \\
\text { Longnose dace, Rhinichthys cataractae, River } \\
\text { shiner, Notropis blennius }\end{array}$ & $\begin{array}{l}\text { Typically found in clearer water with lower } \\
\text { velocity main channel habitats. Often areas } \\
\text { include coarse substrate and } \\
\text { aquatic vegetation. }\end{array}$ \\
\hline Slackwater & $\begin{array}{c}\text { Largemouth bass, Micropterus salmoides, } \\
\text { Bluegill, Lepomis macrochirus, Green sunfish, } \\
\text { Lepomis cyanellus, Yellow perch, } \\
\text { Perca flavescens }\end{array}$ & $\begin{array}{l}\text { Inhabits off-channel pools or backwaters } \\
\text { near stream edges. Inhabited areas often } \\
\text { lower in velocity and greater depths. }\end{array}$ \\
\hline Habitat Generalist & $\begin{array}{l}\text { White sucker, Catostomus commersonii, Creek } \\
\text { chub, Semotilus atromaculatus, Shorthead } \\
\text { redhorse, Moxostoma macrolepidotum, Age } 0 \\
\text { River carpsucker, Carpiodes carpio }\end{array}$ & $\begin{array}{c}\text { Inhabit a wide range of areas within river } \\
\text { channel and backwaters. May include areas } \\
\text { with lower dissolved oxygen and } \\
\text { fluctuating temperatures. }\end{array}$ \\
\hline
\end{tabular}

\subsection{Guild Specific Habitat Suitability}

We used multiple logistic regression models to compute habitat selection for fish habitat guilds. The habitat characteristics collected at each HMU where a PAE was located were the independent variables and the presence and abundance of representatives of the fish habitat guilds were the dependent variables. Habitat characteristics used in the model were those measured during the habitat mapping survey (discussed above). We employed a stepwise forward logistic regression model to identify the habitat characteristics that were used for each fish guild. We used Akaike's information criteria (AIC) to determine which habitat characteristics were included in the regression formula:

$$
R=e^{-z},
$$


where $e$ is the natural-log base and $z=b 1 \times 1+b 2 \times 2+\ldots+b n \cdot x n+$ a $(x n$ are the habitat characteristics, $b \mathrm{n}$ are the regression coefficients, and $a$ is the constant). We included HMUs where fish were caught to distinguish suitable habitat from unsuitable. In a second model, we classified fish habitat guilds as either low or high abundance in each HMU. We calculated guild specific cut-off values for low or high abundance from observed abundances within HMUs. The logistic regression functions highlighted environmental attributes that significantly corresponded with fish habitat guild presence and abundance and the regression coefficients indicated the strength and direction (+ or -) of the association. We calculated the probability of guild presence or abundance for each HMU using the regression equations and the following formula:

$$
P=\frac{e^{z}}{1+e^{z}}
$$

where $P$ is the probability of presence or high abundance, $e$ is the constant, and $z=b 1 \cdot \times 1+b 2 \cdot \times 2+\ldots$ $+b n \cdot x n+a$. We used receiver operating characteristic (ROC) curves to assess predictive ability for the presence and abundance models. The area under the ROC curve defines the discrimination capacity of the model based on Mann-Whitney statistics [24]. The inflection point on the ROC curve defines the probability $(P t)$ that has the highest true positive rate and lowest false positive rate and, thus, the best separation of occupied and not occupied areas. We determined separate $P t$ values for the presence and abundance models. We used the resulting $P t$ thresholds to determine suitable habitats as those that had presence $>P t$ and optimal habitats as those that predicted high abundance $>P t$. Each HMU was assigned to unsuitable, suitable, or optimal categories. We quantified the amount of suitable habitat at each target discharge as a proportion of the river channel area.

\subsection{Time-Series Analysis for Variability in Discharge}

We used a time series of river discharge in the Niobrara River to determine periods of drought or flooding that are not characteristic of long-term discharge patterns and may impart stressful habitat conditions (i.e., harsh events) on the fish community. We determined habitat stressor thresholds (HSTs) from frequency of occurrence of such events [15]. We used mean daily discharge data from 1958 to 2010 to create uniform continuous under-threshold habitat duration curves (UCUT curves; [15,16,25]) used for identifying HSTs. Each incremental river discharge value was converted to a habitat value using the habitat-discharge rating curves. The UCUT curves demonstrate changes in the duration and frequency of habitat availability (i.e., \% channel area available for each fish guild) for a given bioperiod [15]. The procedure identifying HSTs has two steps: (1) Determination of habitat threshold magnitude by selecting curves on the graphs, and (2) identification of persistent durations by locating critical points of the curve. Interpretation of these patterns was based on the following observations: (1) The horizontal distance between curves indicates the change in the frequency of events associated with a habitat increase to the next level (i.e., the larger the distance between two curves at the same continuous duration, the larger the change in the frequency of habitat events), (2) steep curves represent low change in habitat event frequency, and (3) critical points reflect rapid change in frequency of continuous durations. In this way, we identified three categories of habitat event durations for each HST: Typical, persistent, and catastrophic for rare and common HSTs. A persistent event is likely to occur every few years, but at the intra-annual scale, these long events are unusual (i.e., do not happen more than twice in a year). Catastrophic events are assumed to occur on a decadal-scale. The HSTs are labelled as base, trigger, and subsistence discharges. In this context the habitat stress occurs when the amount of suitable habitat is limited for periods that are not commensurate with long-term 'average' levels of variability. Hence, HSTs are defined by habitat availability occurring with rare and common frequency and duration. The discharge value corresponding with rare and common events are labelled subsistence and base discharges HSTs. We identified a trigger HST discharge by finding the first UCUT curve to the right of the subsistence (rare) HST. The HSTs were estimated and organized by bioperiods (i.e., early spawning, 1 March to 14 May; late spawning, 15 May to 30 June; 
summer rearing and growth (1 July to 30 September; overwinter early, 1 October to 31 December; overwinter late, 1 January to 28 February). We acquired river discharge data from the USGS gauging station at Verdel (USGS Gauge 06465500) to create discharge records for Segments 1 and 2, and the Sparks gauge (USGS Gauge 06461500) to create a discharge record for Segment 3.

\section{Results}

We deployed 214 PAE grids to sample the Niobrara River fish community. The number of PAE grids used per study site (i.e., the number of HMUs sampled) ranged from 13 to 24 with an average of 17 PAE grids per study site. We collected 3345 fish representing 30 species and eight families. The results of multiple logistic regression calculations are presented in Table 2. Area under ROC curve values ranged from $54 \%$ to $86 \%$. The habitat suitability model for the lobate margin guild used fish and habitat data from 24 PAE grids where lobate margin species were captured and nine PAE grids with high abundance of these species. The presence model for the lobate margin guild consisted of a number of habitat attributes that described HMUs with moderate velocities $\left(15-30 \mathrm{~cm} \mathrm{~s}^{-1}\right)$ and depths $>125 \mathrm{~cm}$. The abundance model for the lobate margin guild suggested an affinity for slightly greater water velocities (75-90 $\mathrm{cm} \mathrm{s}^{-1}$ ). The habitat suitability model for the run guild used fish and habitat data from 69 PAE grids where run species were captured and 27 PAE grids with high abundance of these species. The presence model for the run guild consisted of a number of habitat attributes that described shallow HMUs with eroded banks and woody debris. The abundance model for the run guild suggested an affinity to higher velocities up to $90 \mathrm{~cm} \mathrm{~s}^{-1}$ and gigalithal (i.e., bedrock) substrates. The habitat suitability model for the riffle guild used fish and habitat data from 124 PAE grids where riffle species were captured and 51 PAE grids with high abundance of these species. The presence model for the riffle guild consisted of a number of habitat attributes that described rocky substrates and moderately deep (50-75 cm) HMUs, but a negative response to main lobes. The abundance model for the riffle guild suggested an affinity to moderate velocities (30-45 $\mathrm{cm} \mathrm{s}^{-1}$ ). The habitat suitability model for the slackwater guild used fish and habitat data from 85 PAE grids where slackwater species were captured and 34 PAE grids with high abundance of these species. The presence model for the slackwater guild suggested gravel substrates and a range of depths were important characteristics for the slackwater guild to be present at a HMU. The abundance model for the slackwater guild suggested an affinity for shallow depths and an aversion for run HMUs. The habitat suitability models for the habitat generalist guild used fish and habitat data from 13 PAE grids where habitat generalist species were captured and six PAE grids with high abundance of this species. The presence model for the habitat generalist guild consisted of a number of habitat attributes that described an aversion for deep $(>125 \mathrm{~cm})$ areas with moderately high velocities $\left(45-60 \mathrm{~cm} \mathrm{~s}^{-1}\right)$. The abundance model for the habitat generalist guild suggested an affinity to moderately deep areas and avoidance of moderately high velocities.

The frequency of HMUs considered non-suitable, suitable, suitable, or optimal varied for fish guilds among river segments (Figure 2). The habitat rating curves suggested suitable habitat generally increased with increasing discharges across all fish habitat guilds and segments during the rearing and growth bioperiod (Figure 3). The lobate margin guild had the greatest amount of available habitat in segment 1 (Figure 3). Suitable habitat for the lobate margin guild was at $14 \%$ channel area (CA) for $0.1 \mathrm{cfsm}, 28 \% \mathrm{CA}$ at $0.2 \mathrm{cfsm}$, and $38 \% \mathrm{CA}$ at $0.45 \mathrm{cfsm}$ in segment 1 . The riffle guild had the least amount of suitable CA in segment 1 never exceeding 5\% CA. The lobate margin guild had the greatest amount of suitable channel area (49\%) of any guild at the highest discharge in segment 2 . The riffle guild had the least amount of suitable habitat available of any guild within segment 2 with a high of $7 \%$ CA at $0.37 \mathrm{cfsm}$. The lobate margin guild had the greatest amount of suitable CA at $0.16 \mathrm{cfsm}$ $(43 \%)$ in segment 3 . The habitat generalist and run guilds were the only two guilds that exhibited a continuous increase in CA available as discharges increased in segment 3 . The slackwater guild had the least amount of available habitat of all the guilds in segment 3 with $13 \% \mathrm{CA}$ at $0.16 \mathrm{cfsm}$. Increases in habitat availability leveled off with increasing discharge at approximately $0.15 \mathrm{cfsm}, 0.13 \mathrm{cfsm}$, and 
$0.07 \mathrm{cfsm}$ for segments 1,2 , and 3, respectively. The relationship between the relative proportions of fish habitat guilds in the existing fish community and the modeled habitat availability suggests habitat and guild composition were generally in similar proportion with a few exceptions (Table 3). For instance, habitat for the lobate margin guild appeared underrepresented in segment 1 (Table 3 ).

Table 2. Multiple logistic regression model results for each habitat guild including area under receiver operator curves (ROC) and beta values of habitat characteristics associated with presence and abundance models to determine suitability and optimal habitat conditions in the Niobrara River. Values in parentheses indicate standard error.

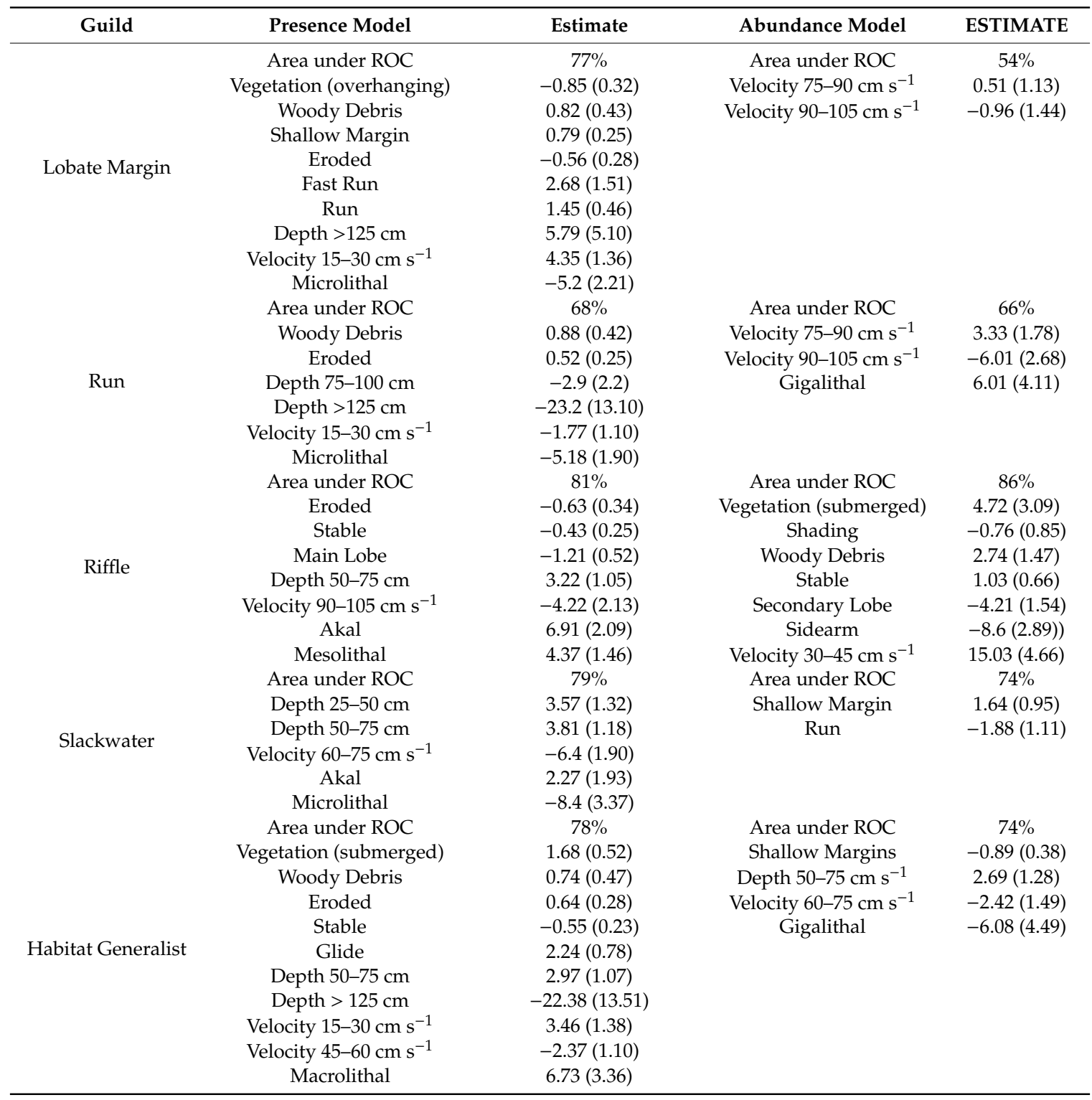


Lobate Margin Guild

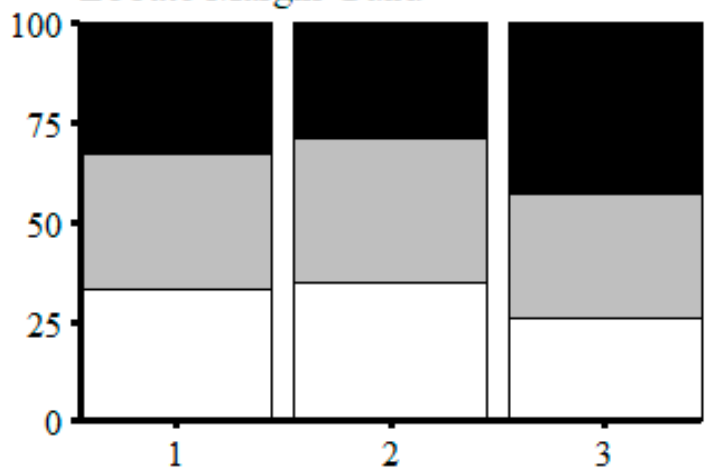

Riffle Guild

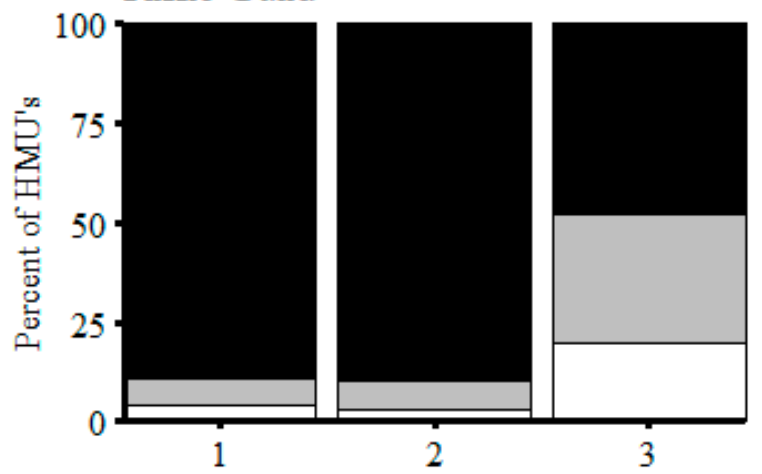

Habitat Generalist Guild

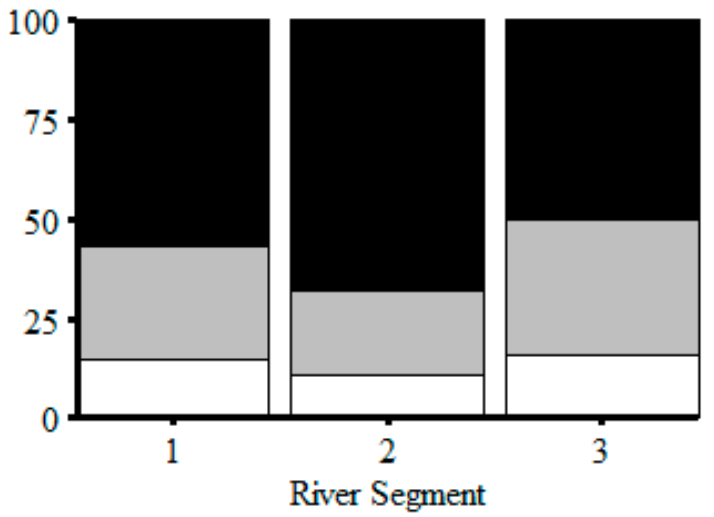

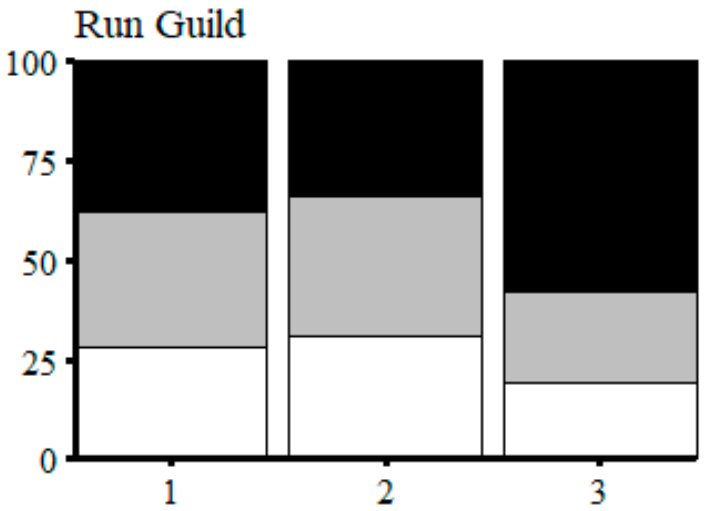

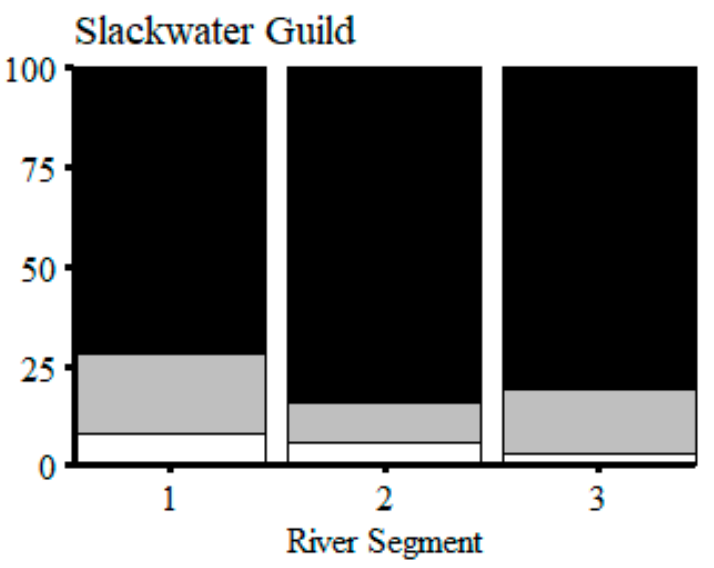

Non Suitable $\square$ Suitable $\longrightarrow$ Optimal

Figure 2. The percentage of hydromorphologic units (HMUs) estimated at non-suitable, optimal, or suitable for each fish guild across river segments of the Niobrara River using predictions from multiple logistic regression models. 

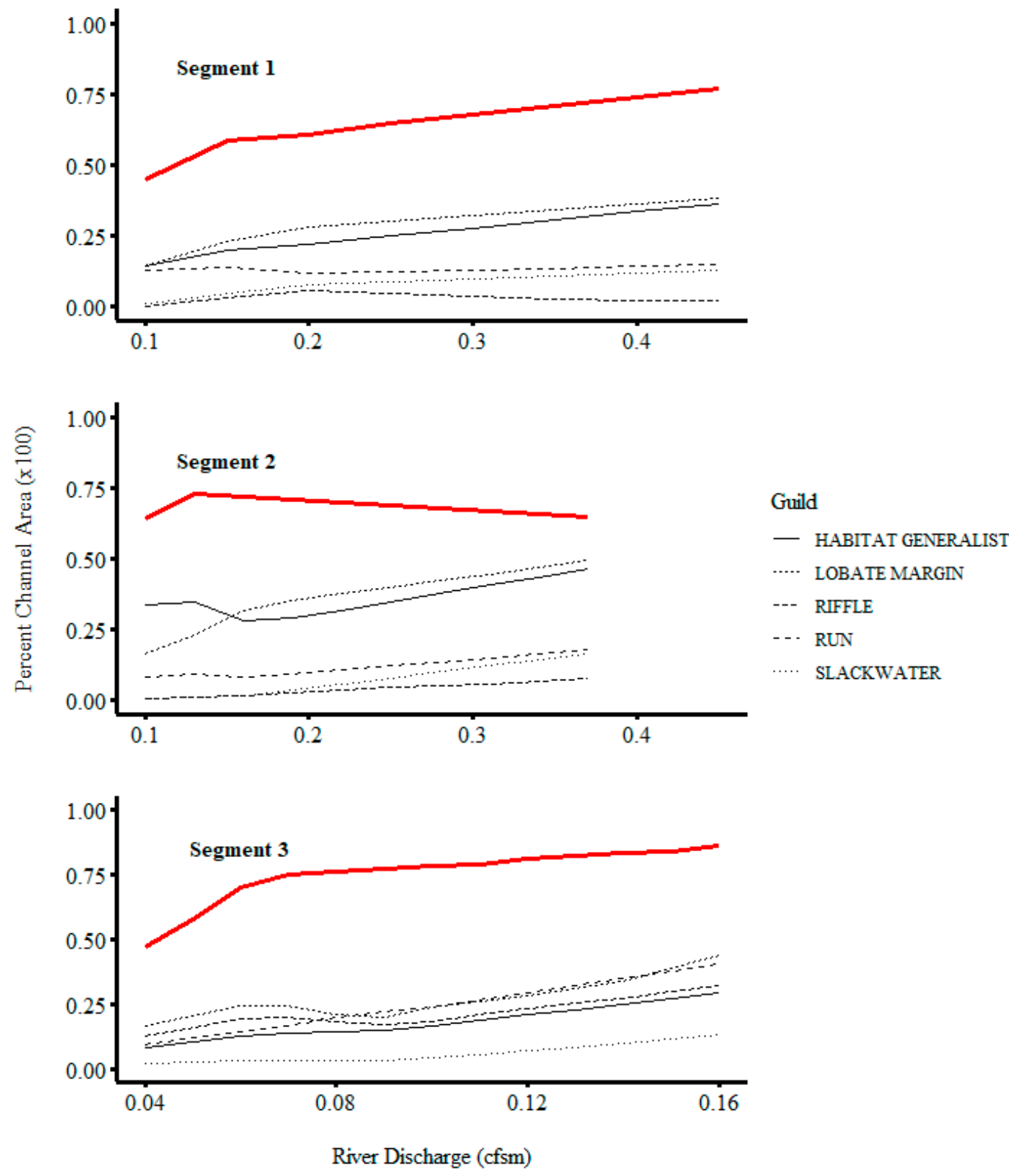

Figure 3. The percent of channel area available to each fish guild across a range of discharges for each river segment of the Niobrara River. The bolded red line is the percentage of the channel area that was considered wetted area. Note different scales used on river discharge axis. Discharge levels are quantified as $\mathrm{ft}^{3} \mathrm{~s}^{-1} \mathrm{mi}^{-1}$ (cfsm).

The river discharge guidelines developed from the habitat time-series analysis describe the variable discharge conditions characteristic of the Niobrara River depending on the bioperiod (Table 4). Base HST discharge values ranged from $0.14 \mathrm{cfsm}$ to $0.19 \mathrm{cfsm}$ among bioperiods in segments 1 and 2 . During the critical period of rearing and growth the base HST discharge threshold was $0.14 \mathrm{cfsm}$ and discharges below this threshold for longer than 92 days may have significant influence on biota (defined as a catastrophic condition, Table 4). Additionally, subsistence HST discharge during the rearing and growth period occurred at $0.05 \mathrm{cfsm}$ and discharges below this threshold for longer than eight days may have a significant influence on biota. Base HST discharge values ranged from $0.09 \mathrm{cfsm}$ to 0.13 cfsm among bioperiods in segment 3. Subsistence HST discharge events ranged from $0.06 \mathrm{cfsm}$ to 0.07 cfsm in segment 3 and may be sustained for durations of five to 21 days depending on the bioperiod. 
Table 3. The percentage composition of the fish community for each guild sampled and the corresponding percentage of suitable habitat available (\% channel area, CA) for each guild at three different discharge levels (discharge levels are quantified as $\mathrm{ft}^{3} \mathrm{~s}^{-1} \mathrm{mi}^{-1}$; cfsm).

\begin{tabular}{|c|c|c|c|c|c|}
\hline \multirow{2}{*}{ Segment } & \multirow{2}{*}{ Guild } & \multirow{2}{*}{$\begin{array}{c}\text { Community } \\
\%\end{array}$} & \multicolumn{3}{|c|}{ Habitat Availability (\%CA) } \\
\hline & & & $0.10 \mathrm{cfsm}$ & $0.25 \mathrm{cfsm}$ & $0.45 \mathrm{cfsm}$ \\
\hline \multirow{6}{*}{1} & Lobate Margin & 47 & 14 & 30 & 39 \\
\hline & Habitat Generalist & 33 & 14 & 25 & 36 \\
\hline & Riffle & 2 & 0 & 5 & 2 \\
\hline & Slackwater & 4 & 1 & 9 & 13 \\
\hline & Run & 14 & 13 & 12 & 15 \\
\hline & & & $0.10 \mathrm{cfsm}$ & $0.22 \mathrm{cfsm}$ & $0.37 \mathrm{cfsm}$ \\
\hline \multirow{6}{*}{2} & Lobate Margin & 22 & 16 & 38 & 49 \\
\hline & Habitat Generalist & 71 & 34 & 32 & 46 \\
\hline & Riffle & 0 & 4 & 3 & 8 \\
\hline & Slackwater & 1 & 1 & 6 & 17 \\
\hline & Run & 6 & 8 & 11 & 18 \\
\hline & & & $0.04 \mathrm{cfsm}$ & $0.10 \mathrm{cfsm}$ & $0.16 \mathrm{cfsm}$ \\
\hline \multirow{5}{*}{3} & Lobate Margin & 39 & 17 & 24 & 44 \\
\hline & Habitat Generalist & 12 & 8 & 17 & 29 \\
\hline & Riffle & 23 & 13 & 19 & 32 \\
\hline & Slackwater & 2 & 2 & 5 & 13 \\
\hline & Run & 24 & 10 & 24 & 40 \\
\hline
\end{tabular}

Table 4. Discharge levels (cfsm) recommended for each bioperiod in all three river segments of the Niobrara River, NE. Bioperiods are based on seasonal changes in precipitation and temperature as well as on life-history stages of fishes and include: Rearing and growth (RG; 1 July to 30 September), overwinter early (OE; 1 October to 31 December), overwinter late (OL; 1 January to 28 February), early spring (ES; 1 March to 14 May), and late spring (LS; 15 May to 30 June). Recommended discharges based on a time series of long-term hydrologic data from the Niobrara River and continuous under threshold (UCUT) analysis [26]. A persistent event is likely to occur every few years, but at the intra-annual scale, these long events are unusual (i.e., do not happen more than twice in a year). Catastrophic events are assumed to occur on a decadal-scale. Discharge levels are quantified as $\mathrm{ft}^{3} \mathrm{~s}^{-1} \mathrm{mi}^{-1}$ (cfsm).

\begin{tabular}{|c|c|c|c|c|c|c|}
\hline \multirow{2}{*}{ Segment } & \multirow{2}{*}{ Discharge Condition } & \multicolumn{5}{|c|}{ Bioperiod } \\
\hline & & RG & OE & OL & ES & LS \\
\hline \multirow{9}{*}{1 and 2} & Base (Common) discharge (cfsm) & 0.14 & 0.16 & 0.17 & 0.19 & 0.19 \\
\hline & Duration under persistent (days) & 32 & 45 & 21 & 18 & 20 \\
\hline & Catastrophic duration (days) & 92 & 92 & 59 & 55 & 47 \\
\hline & Trigger Discharge (cfsm) & 0.06 & 0.10 & 0.08 & 0.12 & 0.10 \\
\hline & Duration under persistent (days) & 8 & 9 & 7 & 7 & 7 \\
\hline & Catastrophic duration (days) & 16 & 18 & 8 & 11 & 11 \\
\hline & Subsistence (Rare) Discharge (cfsm) & 0.05 & 0.08 & 0.06 & 0.11 & 0.09 \\
\hline & Duration under persistent (days) & 5 & 6 & 4 & 3 & 6 \\
\hline & Catastrophic duration (days) & 8 & 10 & 5 & 8 & 9 \\
\hline \multirow{9}{*}{3} & Base (Common) Discharge (cfsm) & 0.09 & 0.12 & 0.13 & 0.10 & 0.10 \\
\hline & Duration under persistent (days) & 47 & 46 & 22 & 39 & 12 \\
\hline & Catastrophic duration (days) & 92 & 92 & 59 & 54 & 29 \\
\hline & Trigger Discharge (cfsm) & 0.06 & 0.07 & 0.08 & 0.07 & 0.07 \\
\hline & Duration under persistent (days) & 11 & 8 & 7 & 6 & 4 \\
\hline & Catastrophic duration (days) & 30 & 25 & 12 & 9 & 6 \\
\hline & Subsistence (Rare) Discharge (cfsm) & 0.06 & 0.06 & 0.07 & 0.07 & 0.07 \\
\hline & Duration under persistent (days) & 10 & 4 & 4 & 3 & 3 \\
\hline & Catastrophic duration (days) & 21 & 6 & 7 & 6 & 5 \\
\hline
\end{tabular}




\section{Discussion}

Assessment of habitat suitability at a river-wide spatial scale and at different river discharges provided insight into the dynamic nature of habitat availability that may influence fish community composition along river systems $[6,27]$. Suitable habitat conditions were available in each river segment of the Niobrara River for each fish guild. The relative proportion of habitat was influenced by the magnitude of discharge. For instance, the lobate margin guild had no less than $30 \%$ of channel area considered suitable habitat across all river segments at the greatest discharge levels modeled but had less than $17 \%$ of the channel area considered suitable habitat at low discharges. The percentage of habitat needed to support the current fish community is unknown. However, the availability and distribution of suitable habitat in the Niobrara River may serve as a conservation baseline for habitat needs to keep the fish community intact [19]. Suitable habitat availability for each fish habitat guild generally increased with increasing discharges. The increase in habitat availability with increasing discharge may be particularly relevant for habitat types that may completely disappear under certain discharge conditions. For instance, riffle and slackwater areas may become greatly diminished at extreme low discharge levels [28]. Our results suggested that habitat availability in segment 1 might be limited for the riffle guild during low discharges. Shallow water habitats used by riffle guild fishes are likely reduced in segment 1 due to limited constraining of river water in the wide and braided channel. In contrast, habitat availability for the riffle guild is consistent across discharges in segment 3 where channel geomorphology (i.e., single channel with defined banks) constrains river water and maintains habitats needed by fishes in the riffle guild. Changes in habitat availability across discharge levels and segments due to geomorphic changes in valley width along the length of the river may influence the composition of the Niobrara River fish community $[17,29]$. Furthermore, if water availability within the Niobrara River changes substantially either through increased human use or changing climate patterns the current structure of fish habitat guilds may be altered as habitat abundance and distribution is tightly linked to discharge patterns.

Discrepancies existed between habitat availability and fish habitat guild structure along the Niobrara River. Fish habitat guilds were not represented proportionately with suitable habitat availability and suggest a mechanism other than habitat alone may influence the presence and abundance of fish guilds. The observed discrepancies between suitable habitat and fish habitat guild composition may result from changes in natural biologic variability due to species mobility and life-history shifts in habitat use [30]. Seasonal migration patterns and multiple life stages present in the river that may not be captured by single survey observations that did not differentiate among life-stage specific habitats. Additionally, species interactions (i.e., competition or predation), may also influence establishment of species throughout available habitats [31]. For instance, non-native species within the Niobrara River have been implicated in shaping macroinvertebrate and fish community structures $[32,33]$.

River discharge guidelines used to protect riverine fishes may benefit from reflecting the intra- and inter-annual variability in discharge that occurred without human modification [34]. Anthropogenic use of river systems, however, has modified river discharge and altered the spatial and temporal dynamics of river systems [1,35]. Elimination of hydrologic variability—including droughts or floods-alters the evolutionary trajectories of fish communities as well as reduces a system's ability to limit invasion by non-native species [36,37]. As such, maintaining the ecological integrity of river systems may be partly dependent on limiting the frequency of conditions that could severely reduce the abundance and distribution of habitats needed by native fishes. Maintaining river discharges consistent with natural variability among bioperiods upholds basic principles of river ecology $[1,3,38]$, and, for the Niobrara River, relies on natural processes that preserve hydrological variability. This approach contradicts current water management policies across U.S. states where water management approaches place emphasis on maintaining consistent discharge targets above maintaining natural variability [34]. For instance, establishment of minimum discharge requirements without explicitly designed variability, are often set for specific durations that typically encompass periods of water withdraw by system users. 
Maintaining a river discharge using minimum criteria is intended to sustain diverse fish communities and initiation of minimum discharges has been shown to increase diversity and abundance of fishes $[9,39]$. However, our study suggests that flexibility in river discharge may better reflect a river's natural hydrograph compared to minimum requirements and may reduce the frequency and intensity of periods of limited habitat availability among diverse fish habitat guilds. Incorporating discharge variability that resembles, to the extent possible, unaltered conditions at river-wide scales may be critical in maintaining aquatic habitats needed to support diverse fish communities [40].

A greater consideration regarding the role and consequences of variability in discharge and changes in habitat patterns at river-wide scales may benefit river ecosystem restoration efforts. With increased demands for water, the potential exists for changes to habitat quantity and quality along the Niobrara River. However, by understanding the consequences of changing river discharge cycles on the associated changes in available habitat for fish habitat guilds we may avert negative impacts (e.g., fish species diversity loss) and allow the Niobrara River, and other similar systems, to maintain native species diversity. Furthermore, ecosystem processes critical in maintaining ecosystem health may not be provided through instituting minimum in-stream discharge alone.

Author Contributions: Conceptualization, M.P. and P.P.; Methodology, M.P. and P.P.; Formal analysis, M.P., P.P., J.R., and J.S.; writing—original draft preparation, J.S., M.P.; writing—review and editing, J.S., M.P., and P.P.; visualization, J.S.

Funding: This project was funded by the Nebraska Game and Parks Commission through the Sportfish Restoration Act and Nebraska Environmental Trust. This research was also supported by the Nebraska Agricultural Experiment Station with funding from the Hatch Multistate Research capacity funding program to M.A. Pegg (project NC-1189) from the USDA National Institute of Food and Agriculture.

Acknowledgments: We thank members of the Nebraska Game and Parks Commission including Richard Holland and Larry Hutchison for project guidance and assistance, Michelle Koch and Rachel Simpson for access to the Nebraska Heritage database. We thank Greg Wanner from the US Fish and Wildlife Service; Pam Sprenkle from the US National Park Service for assistance in access and permitting; Lt. Frank Peck from the Nebraska Highway Patrol for aerial reconnaissance; Jason Alexander from the US Geological Survey for GIS data and geomorphic delineation; Edward Peters and James Parham for supporting information from the Platte River habitat suitability assessment; Adam Behmer for data collection. We thank the anonymous reviewers for comments and suggestions that aided this manuscript.

Conflicts of Interest: The authors declare no conflict of interest.

\section{References}

1. Bunn, S.E.; Arthington, A.H. Basic principles and ecological consequences of altered flow regimes for aquatic biodiversity. Environ. Manag. 2002, 30, 492-507. [CrossRef]

2. Humphries, P.; Neckeis, H.; Finlayson, B. The river wave concept: Integrating river ecosystem models. BioScience 2014, 64, 870-882. [CrossRef]

3. Poff, N.L.; Allan, J.D.; Bain, M.B.; Karr, J.R.; Prestegaard, K.L.; Richter, B.D.; Sparks, R.E.; Stromberg, J.C. The natural flow regime: A new paradigm for riverine conservation and restoration. BioScience 1997, 47, 769-784. [CrossRef]

4. Thoms, M.C.; Parsons, M. Identifying spatial and temporal patterns in the hydrological character of the Condamine-Balonne River, Australia, using multivariate statistics. River Res. Appl. 2003, 19, 443-457. [CrossRef]

5. Jowett, I.G. In-stream flow methods: A comparison of approaches. River Res. Appl. 1996, 13, $115-127$. [CrossRef]

6. Lamouroux, N.; Capra, H.; Pouilly, C.; Souchon, Y. Fish habitat preferences in large streams of Southern France. Freshw. Biol. 1999, 42, 673-687. [CrossRef]

7. Matthews, W.J.; Marsh-Matthews, E. Effects of drought on fish across axes of space, time and ecological complexity. Freshw. Biol. 2003, 48, 1232-1253. [CrossRef]

8. Lamouroux, N.; Souchon, Y. Simple predictions of in-stream habitat model outputs for fish habitat guilds in large streams. Freshw. Biol. 2002, 47, 1531-1542. [CrossRef] 
9. Lamouroux, N.; Oliver, J. Testing predictions of changes in fish abundance and community structure after flow restoration in four reaches of a large river (French Rhone). Freshw. Biol. 2015, 60, 1118-1130. [CrossRef]

10. Persinger, J.W.; Orth, D.J.; Averett, A.W. Using habitat guilds to develop habitat suitability criteria for a warmwater stream fish assemblage. River Res. Appl. 2011, 27, 956-966. [CrossRef]

11. Aarts, B.G.W.; Nienhuis, P.H. Fish zonations and guilds as the basis for assessment of ecological integrity of large rivers. Hydrobiologia 2003, 500, 157-178. [CrossRef]

12. Leonard, P.M.; Orth, D.J. Use of habitat guilds of fishes to determine in-stream flow requirements. N. Am. J. Fish. Manag. 1988, 8, 399-409. [CrossRef]

13. Welcomme, R.L.; Winemiller, K.O.; Cowx, I.G. Fish environmental guilds as a tool for assessment of ecological condition of rivers. River Res. Appl. 2006, 22, 377-396. [CrossRef]

14. Perkin, J.S.; Gido, K.B.; Falke, J.A.; Fausch, K.D.; Crockett, H.; Johnson, E.R.; Sanderson, J. Groundwater declines are linked to changes in Great Plains stream fish assemblages. Proc. Natl. Acad. Sci. USA 2017, 114, 7373-7378. [CrossRef]

15. Parasiewicz, P. Developing a reference habitat template and ecological management scenarios using the MesoHABSIM model. River Res. Appl. 2007, 23, 924-932. [CrossRef]

16. Vezza, P.; Parasiewicz, P.; Spatrani, M.; Comoglio, C. Habitat modeling in high-gradient streams: The mesoscale approach and application. Ecol. Appl. 2014, 24, 844-861. [CrossRef] [PubMed]

17. Alexander, J.S.; Zelt, R.B.; Schaepe, N.J. Hydrogeomorphic and Hydraulic Habitats of the Niobrara River, Nebraska-with Special Emphasis on the Niobrara National Scenic River; U.S. Geological Survey Scientific Investigations Report: Denver, CO, USA, 2010.

18. McManamay, R.A.; Bevelhimer, M.S.; Kao, S.C. Updating the US hydrologic classification: An approach to clustering and stratifying ecohydrologic data. Ecohydrology 2014, 7, 903-926. [CrossRef]

19. Fischer, J.R.; Paukert, C.P. Habitat relationships with fish assemblages in minimally disturbed Great Plains regions. Ecol. Freshw. Fish. 2008, 17, 597-609. [CrossRef]

20. Bain, M.B.; Finn, J.T.; Booke, H.E. A quantitative method for sampling riverine microhabitats by electrofishing. N. Am. J. Fish. Manag. 1985, 5, 489-493. [CrossRef]

21. Austrian Standard ONORM 6232. Richtlinien fuer die oekologische Untersuchung und Bewertung von Fleissgewaessern; Oesterreichische Normungsinstitut: Vienna, Austria, 1995.

22. Milligan, G.W.; Cooper, M.C. An examination of procedures for determining the number of clusters in a data set. Psychometrika 1985, 50, 159-179. [CrossRef]

23. Pegg, M.A.; Behmer, A.T.; Parasaweicz, P.; Rogers, J.N. Application of mesohabitat fish use information to identify guilds for lotic systems. J. Appl. Ichthyol. 2014, 30, 1065-1068. [CrossRef]

24. Pearce, J.; Ferrier, S. Evaluating the predictive performance of habitat models developed using logistic regression. Ecol. Model. 2000, 133, 225-245. [CrossRef]

25. Capra, H.; Breil, P.; Souchon, Y. A new tool to interpret magnitude and duration of fish habitat variations. River Res. Appl. 1995, 10, 281-289. [CrossRef]

26. Parasiewicz, P. Habitat time-series analysis to define flow-augmentation strategy for the Quinebaug River, Connecticut and Massachusetts, USA. River Res. Appl. 2008, 24, 439-452. [CrossRef]

27. Foubert, A.; Lecomte, F.; Legendre, P.; Cusson, M. Spatial organisation of fish communities in the St. Lawrence River: A test for longitudinal gradients and spatial heterogeneities in a large river system. Hydrobiologia 2018, 809, 155-173. [CrossRef]

28. Aadland, L.P. Stream habitat types: Their fish assemblages and relationship to flow. N. Am. J. Fish. Manag. 1993, 13, 790-806. [CrossRef]

29. Spurgeon, J.J.; Pegg, M.A.; Parasiewicz, P.; Rogers, J. Diversity of river fishes influenced by habitat heterogeneity across hydrogeomophic divisions. River Res. Appl. 2018, 34, 797-806. [CrossRef]

30. Schlosser, I.J.; Angermeier, P.L. Spatial variation in demographic processes of lotic fishes: Conceptual models, empirical evidence, and implications for conservation. Am. Fish. Soc. Symp. 1995, 17, 392-401.

31. Jackson, D.A.; Peres-Neto, P.R.; Olden, J.D. What controls who is where in freshwater fish communities-the roles of biotic, abiotic, and spatial factors. Can. J. Fish. Aquat. Sci. 2001, 58, 157-179.

32. Bowles, D.E.; Peitz, D.G.; Cribbs, J.T. Aquatic invertebrate community structure in the Niobrara River, Agate Fossil Beds National Monument, Nebraska, 1996-2009. Great Plains Res. 2013, 23, 1-10. 
33. Spurgeon, J.J.; Stasiak, R.H.; Cunningham, G.R.; Pope, K.L.; Pegg, M.A. Status of native stream fishes within selected protected areas of the Niobrara River in Western Nebraska. Great Plains Res. 2013, 24, 71-78. [CrossRef]

34. Poff, N.L.; Richter, B.D.; Arthington, A.H.; Bunn, S.E.; Naiman, R.J.; Kendy, E.; Acreman, M.; Apse, C.; Bledsoe, B.P.; Freeman, M.C.; et al. The ecological limits of hydrologic alteration (ELOHA): A new framework for developing regional environmental flow standards. Freshw. Biol. 2010, 55, 147-170. [CrossRef]

35. Poff, N.L.; Zimmerman, J.K.H. Ecological responses to altered flow regimes: A literature review to inform the science and management of environmental flows. Freshw. Biol. 2010, 55, 194-205. [CrossRef]

36. Moyle, P.B.; Light, T. Fish Invasions in California: Do abiotic factors determine success? Ecology 1996, 77, 1666-1670. [CrossRef]

37. Perkin, J.S.; Knorp, N.E.; Boersig, T.C.; Gebhard, A.E.; Hix, L.A.; Johnson, T.C. Life history theory predicts long-term fish assemblage response to stream impoundment. Can. J. Fish. Aquat. Sci. 2017, 74, $228-239$. [CrossRef]

38. Orth, D.J. Ecological considerations in the development and application of in-stream flow-habitat models. River Res. Appl. 1987, 1, 171-181. [CrossRef]

39. Travnichek, V.H.; Bain, M.B.; Maceina, M.J. Recovery of warmwater fish assemblage after the initiation of a minimum-flow release downstream from a hydroelectric dam. Trans. Am. Fish. Soc. 1995, 124, 836-844. [CrossRef]

40. Richter, B.; Baumgartner, J.; Wigington, D. How much water does a river need? Freshw. Biol. 1997, 37, 31-249. [CrossRef]

(C) 2019 by the authors. Licensee MDPI, Basel, Switzerland. This article is an open access article distributed under the terms and conditions of the Creative Commons Attribution (CC BY) license (http://creativecommons.org/licenses/by/4.0/). 